\title{
Heterogeneity in Decomposition Rates and Nutrient Release in Fine-Root Architecture of Pinus massoniana in the Three Gorges Reservoir Area
}

\author{
Shao Yang ${ }^{1}$, Ruimei Cheng ${ }^{1,2, *}$, Wenfa Xiao ${ }^{1,2}$, Yafei Shen ${ }^{1}$, Lijun Wang ${ }^{1}$, Yan Guo ${ }^{1}$ \\ and Pengfei Sun ${ }^{1}$ \\ 1 Key Laboratory of Forest Ecology and Environment of National Forestry and Grassland Administration, \\ Research Institute of Forest Ecology, Environment and Protection, Chinese Academy of Forestry, \\ Beijing 100091, China; yangshao82772@163.com (S.Y.); xiaowenf@caf.ac.cn (W.X.); \\ yafeishen126@126.com (Y.S.); 18203686679@163.com (L.W.); gyan1009429073@163.com (Y.G.); \\ flew0130@126.com (P.S.) \\ 2 Co-Innovation Center for Sustainable Forestry in Southern China, Nanjing Forestry University, \\ Nanjing 210037, China \\ * Correspondence: chengrm@caf.ac.cn; Tel.: +86-10-6288-9533
}

Received: 4 November 2019; Accepted: 18 December 2019; Published: 19 December 2019

\begin{abstract}
Fine-root decomposition contributes a substantial amount of nitrogen that sustains both plant productivity and soil metabolism, given the high turnover rates and short root life spans of fine roots. Fine-root decomposition and soil carbon and nitrogen cycling were investigated in a 1-year field litterbag study on lower-order roots (1-2 and 3-4) of Pinus massoniana to understand the mechanisms of heterogeneity in decomposition rates and further provide a scientific basis for short-time research on fine-root decomposition and nutrient cycling. Lower-order roots had slower decay rates compared with higher-order roots (5-6). A significantly negative correlation was observed between the decay constant mass remaining and initial $\mathrm{N}$ concentrations as well as acid unhydrolyzable residues. Results also showed that in lower-order roots (orders 1-2 and 3-4) with a lower C:N ratio, root residual $\mathrm{N}$ was released and then immobilized, whereas in higher-order roots (order 5-6) with a higher C:N ratio, root residual $\mathrm{N}$ was immobilized and then released in the initial stage. In the later stage, $\mathrm{N}$ immobilization occurred in lower-order roots and $\mathrm{N}$ release in higher-order roots, with the C:N ratio gradually decreasing to about 40 in three branching-order classes and then increasing. Our results suggest that lower-order roots decompose more slowly than higher-order roots, which may result from the combined effects of high initial $\mathrm{N}$ concentration and poor $\mathrm{C}$ quality in lower-order roots. During the decomposition of P. massoniana, $\mathrm{N}$ release or $\mathrm{N}$ immobilization occurred at the critical C:N ratio.
\end{abstract}

Keywords: decomposition; root order; Pinus massoniana; Carbon quality; Initial nitrogen concentration

\section{Introduction}

In terrestrial ecosystems, fine-root decomposition plays an important role in nutrient cycling and soil C sequestration [1-4]. Fine roots account for about half of the net primary productivity in forest ecosystems [5]. Recent studies have suggested that input of organic matter during fine-root decomposition promotes greater changes in stable soil organic matter (SOM) and nutrients in the surrounding soil environment compared with SOM input in aboveground ecosystems [3,6]. Despite root diameter significantly affecting root decay, which integrates physiochemical traits associated with root diameter, $<5 \%$ of previous plant decomposition experiments have included belowground assessments. Most previously reported belowground assessments have focused on traditional fine-root 
decomposition ( $\leq 2 \mathrm{~mm}$ in diameter) instead of examining the rapid turnover of the smallest distal roots [7]. Increasingly, evidence indicates that differences in root quality are caused by differences in root diameter. In addition, very fine roots are physiologically more active than larger ones (e.g., $<0.5 \mathrm{~mm}$ versus $0.5-1.0 \mathrm{~mm}$ or $0.5-2.0 \mathrm{~mm}$ ) [8-15].

However, in fine-root decomposition studies, the use of arbitrary diameter cutoffs $(0.5,1.0$, or $2.0 \mathrm{~mm}$ ) masks important differences between different-sized fine roots in longevity, turnover, tissue chemistry, anatomy, metabolism, and decomposition [7,8,16-22]. Hence, recent research has focused on methods based on root order and functional classification to define fine roots [23]. For example, root tips are first-order roots and roots branching from first-order roots are second-order roots. Lower order roots (forth and below) have a high $\mathrm{N}$ concentration because of the absorptive function $\left(\mathrm{NO}^{3-}\right)$ of lower order roots and their higher metabolism, which includes higher proteins and enzymes concentrations [7]. It is generally thought that as fine root order increases, cortex thickness and mycorrhizal colonization decrease in woody plants [17,24]. In addition, uptake capacity decreases with increasing fine root order, while transport capacity increases [19]. Higher order roots (fifth order and above) are involved in water and nutrient transport and have thickened cell walls and increased concentrations of suberin, a biopolymer composed of aliphatic and aromatic compounds, protecting roots from pathogens and desiccation [25-27]. Such branching-order classification better reflects the heterogeneity in decomposition rates of fine roots [7,13]. In a meta-analysis, Lin et al. [28] reported that the decomposition heterogeneity of fine roots was only related to root branching order and not root diameter. To the best of our knowledge, there are only a few previous studies that have focused on fine-root decomposition using branching-order classification of tree species [29-32]. Furthermore, all such studies have reported the same results, i.e., that lower-order roots decompose more slowly than higher-order roots.

In the 1980s, as a native pioneer conifer species, Pinus massoniana forests were commonly used for the reforestation of subtropical China [33,34], including the Three Gorges Reservoir Area of the Yangtze River where P. massoniana is widely distributed and acts as an ecological cornerstone species, which are increasingly important carbon sinks [35]. However, there have been few studies performed on fine-root decomposition and nutrient cycling of P. massoniana. In the two previous studies on the decomposition of fine roots [36,37], the results regarding the regularity of decomposition do not agree. It is possible that arbitrary diameter cutoffs may mask decomposition heterogeneity within fine-root branching systems [28].

Increasing evidence indicates that smaller fine roots decay more slowly than larger ones. To explain this unusual phenomenon, the "N inhibition hypothesis" was proposed by Berg and Mcclaugherty [38]. This hypothesis states that plant litter high in acid unhydrolyzable residues (AUR) (including aliphatics (i.e., suberin), lignin, and secondary metabolites (i.e., alkaloids, phenylpropanoids, and tannins)) may be suppressed by high initial $\mathrm{N}$ concentrations. In addition, some studies have suggested that very fine roots may produce more defensive secondary metabolites owing to herbivore-induced stress (e.g., insects and nematodes), reducing the $C$ quality (sometimes measured by AUR; the higher the AUR in fine roots, the lower the $\mathrm{C}$ quality) of root tissues, and that ectomycorrhizal (ECM) fungi protect roots from bacterial and fungal pathogens by producing antimicrobial compounds in finer roots [7], resulting in poor $\mathrm{C}$ quality in finer roots. Other studies have reported a higher AUR and lower accessible labile $\mathrm{C}$ in very fine roots [32,36]. Hence, the slow decomposition of very fine roots is due to the inhibition of high initial N concentration and high AUR. However, Parton et al. [4] found that the concentration of initial $\mathrm{N}$ affected the net release of $\mathrm{N}$ over a 10 year decomposition experiment in 21 sites from seven biomes. Talbot et al. [39] reported on decomposition in the model plant Arabidopsis thaliana, and the results indicated that initial $\mathrm{N}$ concentration positively affected $\mathrm{N}$ loss owing to the high- $\mathrm{N}$ substrates more sufficiently meeting microbial demand than low-N substrates. Manzoni et al. [40] used a dataset of 2800 observations with litter divided into 55 types with different initial $\mathrm{N}$ concentrations $(0.03 \%$ to $3 \%$ ) to demonstrate that with more efficient use of N-rich substrates, C-use efficiency tends to decrease. 
It is therefore not clear whether the $\mathrm{C}$ quality and initial $\mathrm{N}$ concentration act alone or together in the decomposition heterogeneity process.

We hypothesized that higher-order roots would have a higher decomposition rate than lower-order fine roots owing to the $\mathrm{C}$ quality and initial $\mathrm{N}$ content of fine roots, which leads to different $\mathrm{C}: \mathrm{N}$ ratios in different root orders, altering the effect of microbes on fine-root decomposition. We used the branch-order method to, firstly, test whether lower-order fine roots have slower decomposition rates by conducting a 1 year field litterbag study of different root orders in Pinus massoniana Lamb. Secondly, we assessed the effect of $\mathrm{C}$ quality and initial $\mathrm{N}$ concentration on root decay rates and investigated nutrient release and immobilization in different root orders.

\section{Materials and Methods}

\subsection{Site Description}

This study site was in Shuanshang $\left(30^{\circ} 46^{\prime} \mathrm{N}, 110^{\circ} 55^{\prime} \mathrm{E}\right)$ of Sixi village in Zigui County, Hubei Province, China (Figure 1a). The site has a subtropical continental monsoon climate. The mean annual precipitation is $1400 \mathrm{~mm}$, most of which falls in April, June, July, and September. The mean annual air temperature ranges from $14{ }^{\circ} \mathrm{C}$ to $16^{\circ} \mathrm{C}$. Soils at the site are Haplic Luvisols based on Chinese soil classification [41]. The SOM was $21.61 \% \pm 2.22 \%$ (mean values \pm standard error) at $0-10 \mathrm{~cm}$ soil depth. The nutrient concentration $\left(\mathrm{mg} \mathrm{g}^{-1}\right)$ was $1.16 \pm 0.16,0.22 \pm 0.05,21.91 \pm 4.78,2.59 \pm 0.58$, and $0.40 \pm 0.07$ for total $\mathrm{N}, \mathrm{P}, \mathrm{K}, \mathrm{Ca}$, and $\mathrm{Mg}$, respectively.

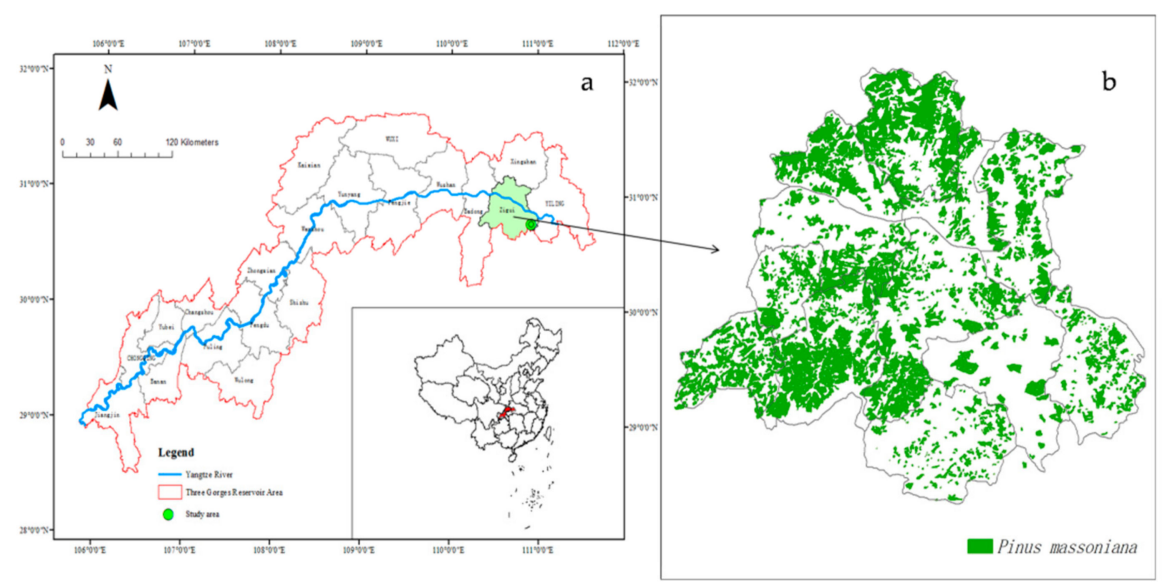

Figure 1. The study area at Shuanshang $\left(30^{\circ} 46^{\prime} \mathrm{N}, 110^{\circ} 55^{\prime} \mathrm{E}\right)$ of Sixi village, indicated by a circle (Zigui City is marked in green) (a) and the distribution of Pinus massoniana in Zigui City (b). The blue line represents the Yangtze River flowing through the Three Gorges Reservoir Area, which is the region within the red line.

A monospecific P. massoniana plantation was selected for our field decomposition experiment with a south-east-facing slope of $15^{\circ}$ and an elevation of 800 to $850 \mathrm{~m}$. In the $1980 \mathrm{~s}$, the plantations were aerially seeded. This forest type was selected because it is the most commonly used indigenous species for reforestation in this area (Figure $1 \mathrm{~b}$ ). The soils exceed $40 \mathrm{~cm}$ in depth with an $\mathrm{O}$ horizon of $\sim 3 \mathrm{~cm}$. Three plots, each $20 \mathrm{~m} \times 20 \mathrm{~m}$, were randomly chosen in the plantation. Within each plot, to minimize the influence of slope, three subplots $(3 \mathrm{~m} \times 3 \mathrm{~m})$ were set up from the top to the bottom of the slopes. The average tree diameter at breast height was $18.30 \mathrm{~cm} \pm 6.93 \mathrm{~cm}$. The mean tree height was $16.96 \mathrm{~m} \pm 5.18 \mathrm{~m}$. The tree density was 675 tree ha \pm 86 tree ha.

\subsection{Decomposition Experiment}

Fine roots of $P$. massoniana trees were excavated from intact soil blocks $(30 \mathrm{~cm} \times 30 \mathrm{~cm} \times 20 \mathrm{~cm})$ in early October 2016. In the P. massoniana plantation, collections were taken $\sim 1 \mathrm{~m}$ from the tree trunk 
to obtain adequate samples of intact fine root segments [42]. The roots were immediately sent to the laboratory after collection and rinsed with deionized water to remove the attached soil particles. The living and dead roots were distinguished in each sample based on the method described by Mcclaugherty et al. [43]. The living roots were then divided into three order classes (order 1-2, order 3-4, and order 5-6) following Pregitzer et al. [13]. The root diameters ( $\mathrm{mm})$ (mean \pm standard errors) from the first- to sixth-order roots of P. massoniana were $0.29 \pm 0.01,0.43 \pm 0.02,0.54 \pm 0.02,0.95 \pm 0.03$, $1.21 \pm 0.07$, and $3.14 \pm 0.10$, respectively. Fine-root decomposition was conducted by the litter bag method. Oven-dried $\left(65^{\circ} \mathrm{C}\right)$ fine roots $(1.000 \pm 0.001 \mathrm{~g})$ of each root order class were placed in nylon mesh bags $(100 \mathrm{~mm} \times 100 \mathrm{~mm})$ with $0.1 \mathrm{~mm}$ diameter holes to prevent meso- and macrofauna from entering. On 17 February, 2017, litterbags were laid within the topsoil (1-10 cm depth). Three different litterbags were randomly collected from one subplot for each root order class (27 litterbags in total at harvest) at 60, 120, 180, 240, and 360 days after incubation from 18 April, 2017 to 12 February, 2018. A total of 135 litterbags per root order class were collected, giving 405 in total (three order classes). The soil was gently washed off using deionized water. Decomposed fine root samples were dried to a constant weight at $65^{\circ} \mathrm{C}$ for $72 \mathrm{~h}$ and weighed with an electronic balance (accurate to $0.0001 \mathrm{~g}$ ).

\subsection{Chemical Analyses}

$\mathrm{HNO}_{3}-\mathrm{H}_{2} \mathrm{O}_{2}$ digestion and inductively coupled plasma-mass spectrometry were used to determine the C and N. P, Mg, K, and Ca content in roots using a Thermo iCAP 6300 (Thermo Scientific., Waltham, MA, USA). Root-C fractions were determined by the forest products serial digestion technique [44,45]. Briefly, the crushed fine root samples were boiled in a $0.5 \mathrm{MH}_{2} \mathrm{SO}_{4}-\mathrm{CTAB}$ solution for $1 \mathrm{~h}$ to remove the extractives (including non-polar and nonstructural components). Then, $72 \% \mathrm{H}_{2} \mathrm{SO}_{4}$ was added to the residue for $3 \mathrm{~h}$ and the mixture fully filtered and rinsed with hot deionized water to remove the acid hydrolyzable residues (AHR) (including cellulose and hemicellulose compounds). The residue was placed in a Muffle furnace at $500{ }^{\circ} \mathrm{C}$ for $4 \mathrm{~h}$ to remove the AUR (lignin, tannin protein complex, and other compounds that are difficult to decompose). The percentage of each component (including extractives, AHR, or AUR) was calculated based on the substances separated at each step.

\subsection{Statistical Analysis}

A single exponential curve for the fractional mass remaining $\left(X_{t} / X_{0}\right)$ over time $t$ was fitted with the model [46]

$$
\ln \left(\mathrm{X}_{\mathrm{t}} / \mathrm{X}_{0}=-k t\right)
$$

where $X_{t}$ is the mass remaining at time $t$ and $X_{0}$ is the original mass. The constants $k$ and $t$ are the decomposition coefficient and the elapsed time (year ${ }^{-1}$ ), respectively [47]. Differences in mass loss and chemical indices across order classes and sample intervals were analyzed with one-way ANOVA, and means were compared using the Bonferroni multiple comparison test with a $5 \%$ rejection level. Linear regression analysis was used to explore the relationships between $k$ and initial $\mathrm{N}$ concentration. Linear and multiple linear regression analysis was used to explore the relationships between decomposition time and remaining N. All statistical analyses were performed using SPSS 22.0 software (SPSS Inc., Chicago, IL, USA).

\section{Results}

\subsection{Initial Fine Roots Chemistry}

The initial $\mathrm{N}$ concentration was significantly different among order classes (Table $1, p<0.001$ ). The initial $\mathrm{N}$ concentration was lower in higher order classes. Clear and significant differences in the initial C:N ratio were observed among order classes. The initial C:N ratio increased in higher order roots, particularly in order $5-6$ (Table $1, p<0.001$ ). In addition, as the order increased, the initial concentration of AUR decreased, but the initial concentration of AHR and extractives increased. The 
initial AUR concentration in order 1-2 was almost 1.19- and 1.31-fold higher than that in order 3-4 and $5-6$, respectively.

Table 1. Initial fine root chemistry (mean \pm standard error $(\mathrm{SE}))(n=3)$.

\begin{tabular}{|c|c|c|c|c|c|c|c|c|c|}
\hline \multirow{2}{*}{$\begin{array}{l}\text { Order } \\
\text { Class }\end{array}$} & \multicolumn{5}{|c|}{ Initial Root Nutrients (mg Element/g Root) } & \multirow{2}{*}{$\begin{array}{c}\text { Ratios } \\
\text { C:N }\end{array}$} & \multicolumn{3}{|c|}{ Initial C Fraction (\%) } \\
\hline & $\mathbf{N}$ & $\mathbf{P}$ & K & $\mathrm{Ca}$ & $\mathrm{Mg}$ & & AUR & AHR & Extractives \\
\hline $1-2$ & $10.22 \pm 0.26^{\mathrm{a}}$ & $0.52 \pm 0.01^{\mathrm{a}}$ & $2.25 \pm 0.07^{\mathrm{a}}$ & $5.95 \pm 0.05^{\mathrm{a}}$ & $1.43 \pm 0.08^{\mathrm{a}}$ & $43.11 \pm 1.01^{\mathrm{a}}$ & $45.27 \pm 2.71^{\text {a }}$ & $22.43 \pm 1.51^{\mathrm{a}}$ & $32.30 \pm 3.01^{\mathrm{a}}$ \\
\hline $3-4$ & $8.55 \pm 0.41^{b}$ & $0.43 \pm 0.03^{b}$ & $1.84 \pm 0.05^{b}$ & $5.23 \pm 0.34^{\mathrm{b}}$ & $1.21 \pm 0.06^{b}$ & $52.00 \pm 2.55^{\mathrm{b}}$ & $38.13 \pm 1.25 \mathrm{ab}$ & $29.17 \pm 1.33^{\mathrm{ab}}$ & $32.70 \pm 2.35^{\mathrm{a}}$ \\
\hline $5-6$ & $7.08 \pm 0.34^{\mathrm{c}}$ & $0.35 \pm 0.01^{c}$ & $1.38 \pm 0.03^{c}$ & $3.97 \pm 0.36^{c}$ & $1.05 \pm 0.06^{\mathrm{c}}$ & $64.22 \pm 3.29^{c}$ & $34.63 \pm 1.90^{\mathrm{b}}$ & $32.30 \pm 2.41^{b}$ & $33.07 \pm 3.73^{\mathrm{a}}$ \\
\hline
\end{tabular}

Different lowercase letters indicate significant differences across order classes $(p<0.05)$. Key to abbreviations: AUR, acid unhydrolyzable residuals; AHR, acid hydrolyzable residuals.

\subsection{Effect of Fine Roots Order Class on Decomposition and N Release Pattern}

The remaining mass pattern can be characterized using a negative exponential model for root order classes (Table 2, Figure 2; $p<0.05$ ). The results indicated an initially rapid mass loss rate (days $0-120$ ) and a later period of slower mass loss (days 120-360) (Figure 2a). Root order 5-6 lost the most mass, followed by order $3-4$ and order $1-2$. On day 120 , the remaining mass was $73.78 \%$ in order $1-2$, $63.89 \%$ in $3-4$, and $60.86 \%$ in $5-6$. After 360 days, the remaining mass was $69.44 \%$ in order $1-2,57.41 \%$ in $3-4$, and $54.20 \%$ in $5-6$. The decomposition constant $(k)$ was higher in higher order roots. The $k$ in order $5-6$ was almost 1.7 times that in order $1-2$ (Table 2; $p<0.05$ ).

Table 2. Decomposition rate coefficients obtained by fitting the simple negative exponential model to Pinus massoniana root data after 360 days of field exposure for each order class (all three plots combined) $(p<0.05)$.

\begin{tabular}{cccc}
\hline Root Class & $k\left(\right.$ Year $\left.^{-1}\right)$ & $\boldsymbol{R}^{\mathbf{2}}$ & $p$ \\
\hline Order $1-2$ & $0.37^{\mathrm{a}}$ & 0.80 & $<0.05$ \\
\hline Order $3-4$ & $0.56^{\mathrm{b}}$ & 0.77 & $<0.05$ \\
\hline Order $5-6$ & $0.62^{\mathrm{b}}$ & 0.75 & $<0.05$ \\
\hline
\end{tabular}

Different lowercase letters indicate significant differences across order classes.

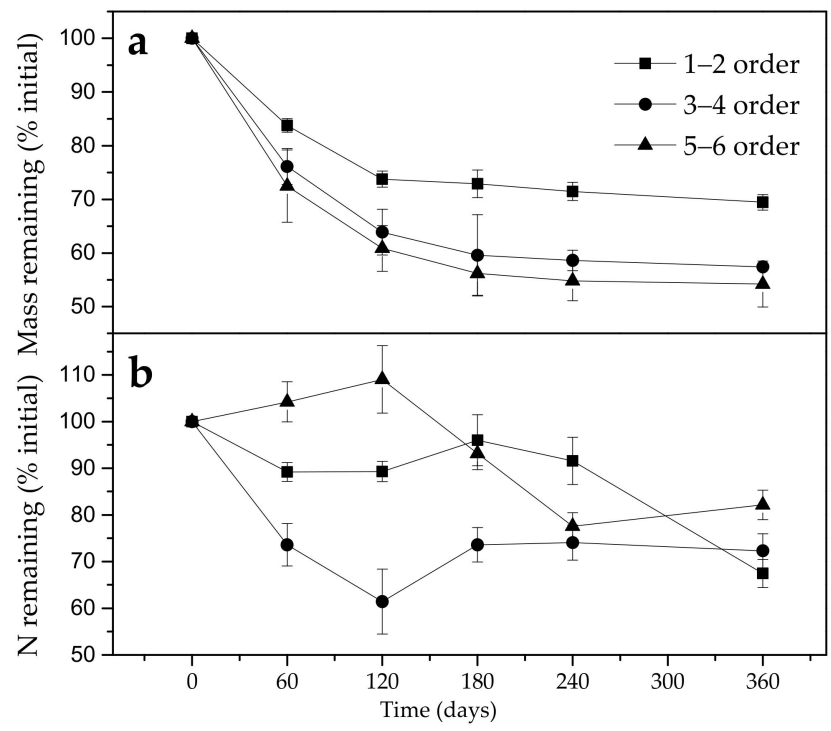

Figure 2. Effects of root order on remaining mass (\% initial) (a) and fraction of initial $\mathrm{N}$ remaining (\% initial) (b) of Pinus massoniana over 360 days of field exposure. Data represent means \pm SE $(n=3)$ (SE not shown if smaller than symbol). 
Both order 1-2 and 3-4 had similar $\mathrm{N}$ release patterns, showing an $\mathrm{N}$ release in the initial stages (days 0-120), and the pattern in residual $\mathrm{N}$ was consistent with an $\mathrm{N}$-immobilization-release trend in later stages (days 120-360) (Figure 2b). For roots in root order 5-6, the pattern in residual $\mathrm{N}$ was consistent with $\mathrm{N}$ being immobilized in the initial period and then released in the later period (Figure $2 b$ ). Three root order classes had similar C:N ratio dynamics, experiencing a decreasing trend from day 0 to day 180 and an increasing-decreasing trend in the later period (except for C:N ratio dynamics of order 1-2 from day 240 to day 360) (Figure 3). In the initial stage, the C:N ratio declined rapidly in the three order classes, particularly in order 5-6. On day 180 , the C:N ratio reached the lowest in the three order classes.

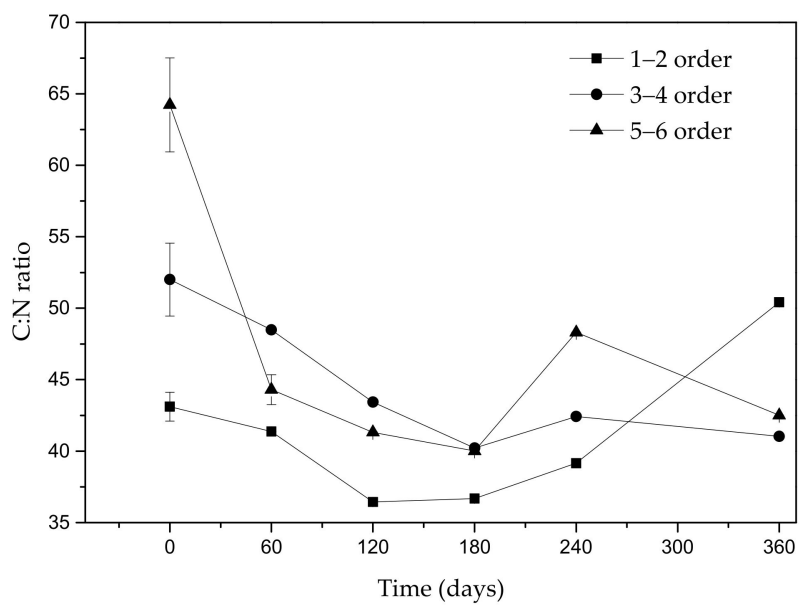

Figure 3. Fraction of initial C:N remaining (\% initial) over 360 days of decomposition for roots of different orders. Data represent means \pm SE $(n=3)$ (SE not shown if smaller than symbol).

\subsection{Linear Relationships between the $k$-Value and Initial Concentrations of $N$ and AUR}

The initial $\mathrm{N}$ concentration explained $81.3 \%$ of the $k$-value during the 360 days of the study for the order classes, respectively (Figure $4 \mathrm{a}, \mathrm{b} ; p<0.001)$. Significant correlations $(p<0.001)$ were observed between the $k$-value and the initial $\mathrm{N}$ concentration in all fine roots (Figure $4 \mathrm{a} ; p<0.001$ ). When all fine roots were pooled, the $k$-value was negatively correlated with initial AUR concentrations (Figure 4b; $p<0.001)$.

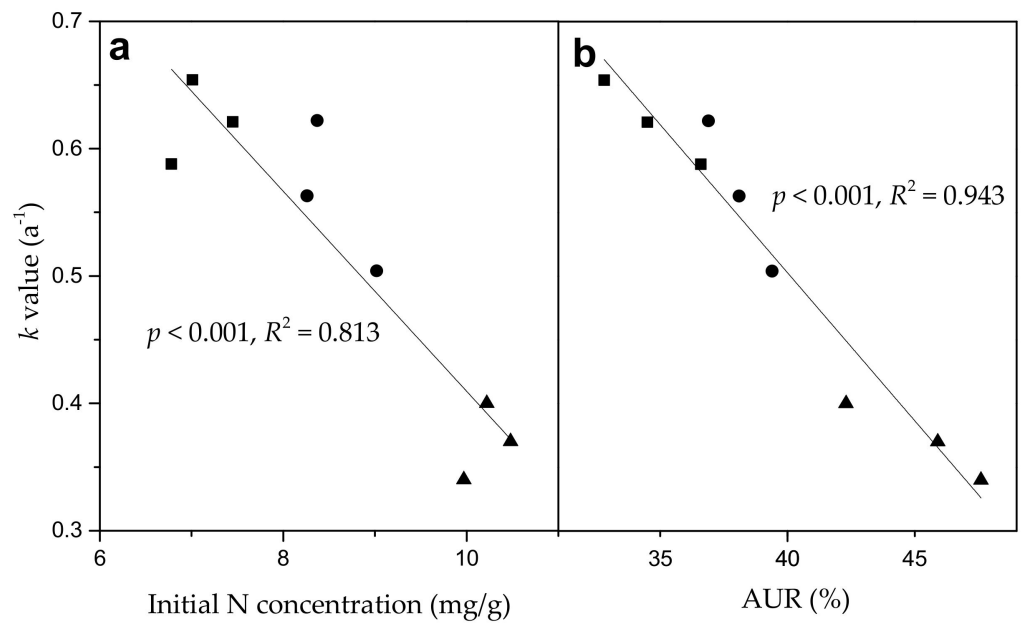

Figure 4. Linear relationship of the decay constant ( $k$-value) with initial $N$ concentration (a) and AUR (b) in the order classes (filled symbols) (orders 1-2 (triangles), 3-4 (circles), and 5-6 (squares)). Over the 360 days of decomposition, significant correlations $(p<0.001)$ were found in all fine roots. The points are values are from the individual plots. 


\section{Discussion}

Fine roots are vital for the link between $\mathrm{C}$ and other biogeochemical cycles such as $\mathrm{N}$ [7]. During the decomposition of fine roots, substantial fractions of $\mathrm{N}$ are contributed to plant productivity and soil metabolism [48]. Tissue chemistry divergence between lower-order and higher-order roots lead to different functions for fine roots, such as plant resource acquisition and transport/storage, thus affecting root decomposition rates [13,18,20,49-51].

Our results showed that fine root decomposition exhibited two evident stages, followed by the initially rapid mass-loss period (0-120 d) and the later slower phase (120-360 d) (Figure 2a). This pattern was consistent with the results of Berg and Mcclaugherty [38] and Yang et al. [52], in which all conifer and broadleaf trees showed a fast decay rate in the initial stage and a slow decay rate in the later phase. In our study, the two stages may be attributed to the initially rapid loss of extractives and the easily degradable AHR, resulting in a rapid period. Then, most of the extractives and AHR were lost and the slow loss of the less readily degradable AUR remained in the fine roots, resulting in a slow period.

Our analysis of fine-root decay based on the branching-order classification revealed that decay rates in the lower-order roots were slower than those of higher-order roots over the 1 year study period. Heterogeneity in decomposition rates appeared to be consistent for woody species [28-32]. Our results indicate that low decomposition rates may be due to the combination of high initial $\mathrm{N}$ concentration and poor C quality (high AUR fractions). One reason for this is that in our study, root order 1-2 had a higher AUR fraction than that of order 3-4. The AUR fraction of the higher-order roots (order 5-6) was lower than that of the lower-order roots (orders 1-2 and 3-4) (Table 1). In addition, our results reveal a significant correlation between the decay constant and AUR (Figure 4b). Other studies have reported similar results for both coniferous and broad-leaved trees $[28,32,36,53]$. Lower-order roots seem to produce more defensive secondary metabolites to defend against herbivores compared with higher-order roots, and ECM fungi protect roots from bacterial and fungal pathogens by producing antimicrobial compounds in finer roots [7]. Thus, the AUR fractions increase, and the root $C$ quality decreases in lower-order roots [54]. This may lead to heterogeneity in decomposition rates between higher-order and lower-order roots. Another reason is that the initial $\mathrm{N}$ concentration decreases as the branching-order class increases (Table 1). Lin et al. [36] have reported the same results in $P$. massoniana fine root decomposition. $\mathrm{N}$ concentration was negatively correlated with the decay rate during decomposition (Figure 4a). These results agree with those of recent studies [29,32,53]. For example, Fan and Guo [25] reported that the mass remaining was significantly correlated with initial N concentration during fine-root decomposition. This may lead to a slower decay rate in lower-order compared to higher-order roots.

In addition, in lower-order roots (orders 1-2 and 3-4) with a lower C:N ratio, root residual $\mathrm{N}$ was released, immobilized, and then released, whereas in higher-order roots (order 5-6) with a higher C:N ratio, root residual $\mathrm{N}$ was immobilized, released, and then immobilized (Figures $2 \mathrm{~b}$ and 3). These patterns can be explained by the demand of microorganisms to synthesize proteins and the fact that high-N root orders (1-2 and 3-4) with a lower C:N ratio meet the demand, causing net $\mathrm{N}$ release in the early stages of decomposition (days 0-120) [40]. The roots initially had a higher C:N ratio (low- $\mathrm{N}$ concentration) than microbes, but $\mathrm{N}$ immobilization from exogenous $\mathrm{N}$ is required to balance the microbial C:N ratio [32,40]. In the later stages of decomposition (days 120-360) when the C:N ratio reached critical values (35-40), root residual $\mathrm{N}$ began to show the opposite trend regarding immobilization or release (Figures $2 b$ and 3 ). These results agree with those from a previous meta-analysis of 2800 observations which reported that the critical value was from 67 to 77 during plant litter decomposition [40]. The results of the meta-analysis, based on a global dataset, indicate that root tissue chemistry is the main driver of root decomposition and especially the $\mathrm{C}: \mathrm{N}$ ratio, rather than climate or other environmental factors [55]. Moreover, Parton et al. [4] reported that the C:N ratio mainly regulates net- $\mathrm{N}$ release based on 21 sites throughout seven biomes in a 10 year litter decomposition experiment. Our study agrees with the results of Fan et al. [29], who found a critical $\mathrm{C}: \mathrm{N}$ ratio for $\mathrm{N}$ release versus immobilization. Our results show that the critical C:N ratio for $\mathrm{N}$ release 
or immobilization is at day 180 and that the C:N ratio first decreased and later increased (Figures $2 \mathrm{~b}$ and 3). One explanation for this was that the $C: N$ ratio decreased due to the rapid loss of extractives and the easily degradable AHR in the initial stage and less $\mathrm{N}$ being released [36], whereas the C:N ratio later increased due to the $\mathrm{N}$ demand of microorganisms to synthesize proteins [39], with most extractives and AHR being lost and the slow loss of the less readily degradable AUR remaining in the fine roots [36].

Consequently, in the initial period, the higher-order roots decomposed faster than the lower-order roots (Figure 2a), which had a higher C quality [54]. However, in the later stage, the lower-order roots had a slower decay rate compared with the higher-order roots (Figure 2a), which had a lower $\mathrm{N}$ concentration.

\section{Conclusions}

Using the branching-order classification, our study provides further evidence to indicate that decomposition rates in lower-order roots are slower than those in higher-order roots, indicating that the heterogeneity in decomposition rates between higher- and lower-order roots is due to a combination of high initial $\mathrm{N}$ concentration and poor $\mathrm{C}$ quality in lower-order roots. We also found that more of the initial $\mathrm{N}$ remained in root orders 1-2 compared with that which remained in orders $3-4$. This suggests that $\mathrm{N}$ release was inhibited by a high initial $\mathrm{N}$ concentration in lower-order roots. The lower-order roots released more $\mathrm{N}$ but at a slower rate than that of higher-order roots. Given the fast turnover rates and short root life spans in lower-order roots, they are the main source of soil-available N. During the decomposition of $P$. massoniana, $\mathrm{N}$ release or $\mathrm{N}$ immobilization occurred at the critical C: $\mathrm{N}$ ratio.

Author Contributions: S.Y. and R.C. conceived and designed the experiments. S.Y. performed the experiments and drafted the manuscript. W.X. gave constructive comments on earlier drafts of the manuscript. Y.S., L.W., Y.G., and P.S. contributed to refining the ideas, carrying out additional analyses, and finalizing this paper. All authors have read and agreed to the published version of the manuscript.

Funding: This work was supported by the National Key Research and Development Program of the Ministry of Science and Technology of China (no. 2016YFD0600204), the Fundamental Research Funds of CAF (no. CAFYBB2017ZA002), and the National Key Research and Development Program of the Ministry of Science and Technology of China (no. 2015BAD07B040301).

Conflicts of Interest: The authors declare that they have no conflicts of interest.

\section{References}

1. Cotrufo, M.F.; Soong, J.L.; Horton, A.J.; Campbell, E.E.; Haddix, M.L.; Wall, D.H.; Parton, W.J. Formation of soil organic matter via biochemical and physical pathways of litter mass loss. Nat. Geosci. 2015, 8, 776-779. [CrossRef]

2. Lal, R. Soil carbon sequestration impacts on global climate change and food security. Science 2004, 304, 1623-1627. [CrossRef] [PubMed]

3. Mambelli, S.; Bird, J.A.; Gleixner, G.; Dawson, T.E.; Torn, M.S. Relative contribution of foliar and fine root pine litter to the molecular composition of soil organic matter after in situ degradation. Org. Geochem. 2007, 42, 1099-1108. [CrossRef]

4. Parton, W.; Silver, W.L.; Burke, I.C.; Grassens, L.; Harmon, M.E.; Currie, W.S.; King, J.Y.; Adair, E.C.; Brandt, L.A.; Hart, S.C.; et al. Global-scale similarities in nitrogen release patterns during long-term decomposition. Science 2007, 315, 361-364. [CrossRef]

5. Freschet, G.T.; Cornwell, W.K.; Wardle, D.A.; Elumeeva, T.G.; Liu, W.; Jackson, B.G.; Onipchenko, V.G.; Soudzilovskaia, N.A.; Tao, J.; Cornelissen, J.H.C. Linking litter decomposition of above and belowground organs to plant-soil feedbacks worldwide. J. Ecol. 2013, 101, 943-952. [CrossRef]

6. Smith, A.R.; Lukac, M.; Bambrick, M.; Miglietta, F.; Godbold, D.L. Tree species diversity interacts with elevated $\mathrm{CO}_{2}$ to induce a greater root system response. Glob. Chang. Biol. 2012, 19, 217-228. [CrossRef]

7. Beidler, K.V.; Pritchard, S.G. Maintaining connectivity: Understanding the role of root order and mycelial networks in fine root decomposition of woody plants. Plant Soil 2017, 420, 19-36. [CrossRef] 
8. Burton, A.J.; Jarvey, J.C.; Jarvi, M.P.; Zak, D.R.; Pregitzer, K.S. Chronic N deposition alters root respiration-tissue $\mathrm{N}$ relationship in northern hardwood forests. Glob. Chang. Biol. 2012, 18, 258-266. [CrossRef]

9. Joslin, J.D.; Gaudinski, J.B.; Torn, M.S.; Riley, W.J.; Hanson, P.J. Fine-root turnover patterns and their relationship to root diameter and soil depth in a 14C-labeled hardwood forest. New Phytol. 2006, 172, 523-535. [CrossRef]

10. Ouimette, A.; Guo, D.; Hobbie, E.; Gu, J. Insights into root growth, function, and mycorrhizal abundance from chemical and isotopic data across root orders. Plant Soil 2013, 367, 313-326. [CrossRef]

11. Park, B.B.; Yanai, R.D.; Fahey, T.J.; Bailey, S.W.; Siccama, T.G.; Shanley, J.B.; Cleavitt, N.L. Fine root dynamics and forest production across a calcium gradient in northern hardwood and conifer ecosystems. Ecosystems 2008, 11, 325-341. [CrossRef]

12. Pregitzer, K.S.; Laskowski, M.J.; Burton, A.J.; Lessard, V.C.; Zak, D.R. Variation in sugar maple root respiration with root diameter and soil depth. Tree Physiol. 1998, 18, 665-670. [CrossRef] [PubMed]

13. Pregitzer, K.S.; Deforest, J.L.; Burton, A.J.; Allen, M.F.; Ruess, R.W.; Hendrick, R.L. Fine root architecture of nine north American trees. Ecol. Monogr. 2002, 72, 293-309. [CrossRef]

14. Rewald, B.; Rechenmacher, A.; Godbold, D.L. It's complicated-intra-root system variability of respiration and morphological traits in four deciduous tree species. Plant Physiol. 2014, 166, 736-745. [CrossRef] [PubMed]

15. Sun, T.; Mao, Z. Functional relationships between morphology and respiration of fine roots in two Chinese temperate tree species. Plant Soil 2011, 346, 375-384. [CrossRef]

16. Eissenstat, D.M.; Wells, C.E.; Yanai, R.D.; Whitbeck, J.L. Building roots in a changing environment: Implications for root longevity. New Phytol. 2000, 147, 33-42. [CrossRef]

17. Guo, D.L.; Mitchell, R.J.; Hendricks, J.J. Fine root branch orders respond differentially to carbon source-sink manipulations in a longleaf pine forest. Oecologia 2004, 140, 450-457. [CrossRef]

18. Guo, D.L.; Xia, M.; Wei, X.; Chang, W.; Liu, Y.; Wang, Z. Anatomical traits associated with absorption and mycorrhizal colonization are linked to root branch order in twenty-three Chinese temperate tree species. New Phytol. 2008, 180, 673-683. [CrossRef]

19. Mccormack, M.L.; Adams, T.S.; Smithwick, E.A.H.; Eissenstat, D.M. Predicting fine root lifespan from plant functional traits in temperate trees. New Phytol. 2012, 195, 823-831. [CrossRef]

20. Valenzuela-Estrada, L.R.; Vera-Caraballo, V.; Ruth, L.E.; Eissenstat, D.M. Root anatomy, morphology, and longevity among root orders in Vaccinium corymbosum (Ericaceae). Am. J. Bot. 2008, 95, 1506-1514. [CrossRef]

21. Valenzuela-Estrada, L.R.; Richards, J.H.; Andres, D.; Eissensat, D.M. Patterns of nocturnal rehydration in root tissues of Vaccinium corymbosum L. under severe drought conditions. J. Exp. Bot. 2009, 60, 1241-1247. [CrossRef] [PubMed]

22. Wells, C.E.; Eissenstat, D.M. Marked differences in survivorship among apple roots of different diameters. Ecology 2001, 82, 882-893. [CrossRef]

23. Du, X.; Wei, X. Definition of fine roots on the basis of the root anatomy, diameter and branch orders of one-year old Fraxinus mandshurica seedlings. J. For. Res. 2018, 29, 1321-1327. [CrossRef]

24. Jia, S.; McLaughlin, N.B.; Gu, J.; Li, X.; Wang, Z. Relationships between root respiration rate and root morphology, chemistry and anatomy in Larix gmelinii and Fraxinus mandshurica. Tree Physiol. 2013, 33, 579-589. [CrossRef] [PubMed]

25. Xia, M.; Guo, D.; Pregitzer, K.S. Ephemeral root modules in fraxinus mandshurica. New Phytol. 2010, 188, 1065-1074. [CrossRef] [PubMed]

26. Adams, T.S.; McCormack, M.L.; Eissenstat, D.M. Foraging strategies in trees of different root morphology: The role of root lifespan. Tree Physiol. 2013, 33, 940-948. [CrossRef]

27. Brunner, I.; Herzog, C.; Dawes, M.A.; Arend, M.; Sperisen, C. How tree roots respond to drought. Front. Plant Sci. 2015, 6, 547. [CrossRef]

28. Lin, G.; Zeng, D.H. Heterogeneity in decomposition rates and annual litter inputs within fine-root architecture of tree species: Implications for forest soil carbon accumulation. For. Ecol. Manag. 2017, 389, 386-394. [CrossRef]

29. Fan, P.; Guo, D. Slow decomposition of lower order roots: A key mechanism of root carbon and nutrient retention in the soil. Oecologia 2010, 163, 509-515. [CrossRef] 
30. Goebel, M.; Hobbie, S.E.; Bulaj, B.; Zadworny, M.; Archibald, D.D.; Oleksyn, J.; Reich, P.B.; Eissenstat, D.M. Decomposition of the finest root branching orders: Linking belowground dynamics to fine-root function and structure. Ecol. Monogr. 2011, 81, 89-102. [CrossRef]

31. Sun, T.; Dong, L.L.; Zhang, L.L.; Wu, Z.J.; Wang, Q.K.; Li, Y.Y.; Zhang, H.G.; Wang, Z.W. Early stage fine-root decomposition and its relationship with root order and soil depth in a Larix gmelinii plantation. Forests 2016, 7, 234. [CrossRef]

32. Xiong, Y.; Fan, P.; Fu, S.; Zeng, H.; Guo, D.L. Slow decomposition and limited nitrogen release by lower order roots in eight Chinese temperate and subtropical trees. Plant Soil 2013, 363, 19-31. [CrossRef]

33. Cheng, C.; Wang, Y.; Fu, X.; Xu, M.; Dai, X.; Wang, H.M. Thinning effect on understory community and photosynthetic characteristics in a subtropical Pinus massoniana plantation. Can. J. For. Res. 2017, 47, 1104-1115. [CrossRef]

34. Zhang, S.; Huang, J.G.; Rossi, S.; Ma, Q.; Yu, B.; Zhai, L.; Luo, D.; Guo, X.; Fu, S.; Zhang, W. Intra-annual dynamics of xylem growth in Pinus massoniana submitted to an experimental nitrogen addition in Central China. Tree Physiol. 2017, 37, 1546-1553. [CrossRef]

35. Piao, S.L.; Fang, J.Y.; Ciais, P.; Peylin, P.; Huang, Y.; Sitch, S.; Wang, T. The carbon balance of terrestrial ecosystems in China. Nature 2009, 458, 1009-1013. [CrossRef]

36. Lin, C.; Yang, Y.; Guo, J.; Chen, G.; Xie, J. Fine root decomposition of evergreen broadleaved and coniferous tree species in mid-subtropical china: Dynamics of dry mass, nutrient and organic fractions. Plant Soil 2011, 338, 311-327. [CrossRef]

37. Shen, Y.F.; Wang, N.; Cheng, R.M.; Xiao, W.; Yang, S.; Guo, Y. Characteristics of fine roots of Pinus massoniana in the Three Gorges Reservoir Area, China. Forests 2017, 8, 183. [CrossRef]

38. Berg, B.; Mcclaugherty, C. Plant Litter-Decomposition, Humus Formation, Carbon Sequestration; Springer: Berlin, Germany, 2003. [CrossRef]

39. Talbot, J.M.; Treseder, K.K. Interactions among lignin, cellulose, and nitrogen drive litter chemistry-decay relationships. Ecology 2012, 93, 345-354. [CrossRef]

40. Manzoni, S.; Jackson, R.B.; Trofymow, J.A.; Porporato, A. The global stoichiometry of litter nitrogen mineralization. Science 2008, 321, 684-686. [CrossRef]

41. Gong, Z.T. Chinese Soil Taxonomy; China Science Press: Beijing, China, 2003. [CrossRef]

42. Wang, R.; Cheng, R.; Xiao, W.; Feng, X.; Liu, Z.; Wang, X. Influencing factors of fine root production and turnover in forest ecosystem. World For. Res. 2012, 25, 19-24, (In Chinese with English Abstract).

43. Mcclaugherty, C.A.; Aber, J.D.; Melillo, J.M. The role of fine roots in the organic matter and nitrogen budgets of two forested ecosystems. Ecology 1982, 63, 1481-1490. [CrossRef]

44. Ryan, M.G.; Melillo, J.M.; Ricca, A. A comparison of methods for determining proximate carbon fractions of forest litter. Can. J. For. Res. 1990, 20, 166-171. [CrossRef]

45. Hendricks, J.J.; Aber, J.D.; Nadelhoffer, K.J.; Hallett, R.D. Nitrogen controls on fine root substrate quality in temperate forest ecosystems. Ecosystems 2000, 3, 57-69. [CrossRef]

46. Olson, J.S. Energy storage and the balance of producers and decomposers in ecological systems. Ecology 1963, 44, 322-331. [CrossRef]

47. Wieder, R.K.; Lang, G.E. A critique of the analytical method used in examining decomposition data obtained from litter bags. Ecology 1982, 63, 1636-1642. [CrossRef]

48. Fan, P.; Jiang, Y. Nitrogen dynamics differed among the first six root branch orders of Fraxinus mandshurica and Larix gmelinii during short-term decomposition. J. Plant Res. 2010, 123, 433-438. [CrossRef]

49. McCormack, M.L.; Dickie, I.A.; Eissenstat, D.M.; Fahey, T.J.; Fernandez, C.W.; Guo, D.L. Redefining fine roots improves understanding of below-ground contributions to terrestrial biosphere processes. New Phytol. 2015, 207, 505-518. [CrossRef]

50. Copley, J. Ecology goes underground. Nature 2000, 406, 452-454. [CrossRef]

51. Morgan, J.A. Looking beneath the Surface. Science 2002, 298, 1903-1904. [CrossRef]

52. Yang, Y.S.; Chen, G.S.; Guo, J.F.; Lin, P. Decomposition dynamic of fine roots in a mixed forest of Cunninghamia lanceolata and Tsoongiodendron odorum in mid-subtropics. Ann. For. Sci. 2004, 61, 65-72. [CrossRef]

53. Sun, T.; Mao, Z.; Han, Y. Slow decomposition of very fine roots and some factors controlling the process: A 4-year experiment in four temperate tree species. Plant Soil 2013, 372, 445-458. [CrossRef] 
54. Seastedt, T.R.; Murray, P.; Johnson, S.; Murray, P.J. Root herbivory in grassland ecosystems. Papers Presented at the Workshop: Integrative Approaches for the Investigation of Root Herbivory in Agricultural and Natural Systems, Berkshire, UK, 17 September 2008. [CrossRef]

55. Silver, W.L. Global Patterns in Root Decomposition: Comparisons of climate and litter quality effects. Oecologia 2001, 129, 407-419. [CrossRef] [PubMed]

(C) 2019 by the authors. Licensee MDPI, Basel, Switzerland. This article is an open access article distributed under the terms and conditions of the Creative Commons Attribution (CC BY) license (http://creativecommons.org/licenses/by/4.0/). 